\title{
The Antimicrobial Activity of Citrus limon L. against Foodborne Pathogens and Its Anti-Oxidant and Antibiofilm Properties
}

\author{
Research Article
}

\section{Ökmen $\mathbf{G}^{1 *}$, Arslan $\mathrm{K}^{1}$, Tekin $\mathbf{R}^{\mathbf{1}}$}

1. Mugla Sitki Kocman University, Faculty of Science, Department of Biology, 48000, Mugla, Turkey.

\begin{abstract}
The objective of this study is to develop a new and effective antibacterial agent against food pathogens that poses a major threat to human health and to investigate the antioxidant activity of this plant. Methanol, ethanol, and aqueous extracts were analyzed for antimicrobial potency. Eight different microorganisms were used in the study, one of which was yeast. These microorganisms are food pathogens. Antimicrobial activity testing was performed using a disc diffusion method. Another test for antimicrobial activity is the minimum inhibitory level. Antioxidant activity was conducted using 2,2-azinobis-(3-ethylbenzothiazoline-6-sulfonic acid) (ABTS•) and 1,1-diphenyl-2picrylhydrazyl (DPPH•). Citrus limon ethanol extract had a maximum inhibiting zone against Escherichia coli (12 $\mathrm{mm}$ ). In the ABTS method, the highest scavenging activity was obtained from an ethanol extract (58.3 percent). The methanol extract (95.4\%) led to the largest DPPH scavenging activity. Consequently, Citrus limon extracts have antimicrobial, antioxidant, and anti-biofilm potential against foodborne pathogens.
\end{abstract}

Key Words: Citrus, Food pathogen, Antimicrobial activity, Antioxidant activity, Antibiofilm activity, TLC.

\section{Introduction}

Microbial damage to food is caused by the uncontrolled growth of undesirable microorganisms. In European countries, over 23 million people get sick every year as a result of eating contaminated food (1). Although chemical antimicrobial agents have been used in food processing for decades to reduce the effect of microbial contamination, the demand for natural food ingredients and additives; Including natural antimicrobial compounds, is now on an upward trend $(2,3,4)$. Herbal drugs are natural whereas in contrast, treatment provided by chemically synthesized drugs has side effects on our body.

Excess drug use has resulted in bacterial resistance (5). As there is an increase in antibiotic resistance to some bacteria, there is always research for an alternative drug $(6,7)$. The issue of microbial resistance to existing antibiotics can become attractive to conventional medicine (8). The issue of resistance of bacteria to antibacterial drugs is one of the most significant global challenges. Furthermore, plantderived antibacterials are attractive because they often lack the many side effects associated with synthetic antibacterials. New antibacterial components from natural sources are therefore being investigated (9).

\section{* Corresponding Author:}

\section{Ökmen G}

Associate Professor,

Mugla Sitki Kocman University,

Faculty of Science,

Department of Biology, TURKEY.

Email Id: gultenokmen@gmail.com
Moreover, bacterial biofilms are surfaceassociated microbial communities contained within an autogenerative exopolysaccharide matrix (10). Biofilms are responsible for about $65 \%$ of all bacterial infections in humans (11). Infection caused by a microorganism is further complicated by its ability to produce biofilms, thereby reducing antimicrobial penetration $(12,13,14)$.

Over the past few years, consumer desire for natural ingredients and preservative-free foods has increased the popularity of natural antimicrobials (15). To this end, the effectiveness of medicinal and aromatic plants and their extracts for food safety and preservation purposes was assessed. The majority of their preservative properties are due to their essential oils (EOs) and other secondary components of plant metabolite (16). EOs have well-known properties, like antimicrobial and antioxidant properties. Herbal medicine has gained a great deal of attention and awareness as a substitute for the treatment or prevention of health-related disorders (17). Today, around $80 \%$ of the world's population relies on local herbal drugs (18). Antimicrobially active herbs and spices have been widely used traditionally and commercially to increase the shelf life and safety of food $(19,20)$. According to the World Health Organization (WHO), medicinal plants are the most important source of drug supplies. Therefore, these plants should be studied for a better understanding of their properties, safety and efficacy (21).

The genus Citrus belongs to the family Rutaceae which comprises about 140 genera and 1300 species and, for example, Citrus limon (Lemon) is amongst the important species of the genus Citrus (22). Citrus is one of the most significant commercial and industrial agricultural activities in the World (23). Turkey is one of the most important nations among 
Citrus growers. The genus Citrus consists of evergreen plants, shrubs or trees (3-15 $\mathrm{m}$ in height). Their leaves are leathery, egg-shaped or elliptical. A few have spikes. The flowers grow individually in the axilla of the leaves. Each flower has 5 petals, white or red. The fruit is a citrus berry. Citrus is naturally occurring in warm and mild climate regions, mainly in the Mediterranean region. They are typically susceptible to frost (24). One of the most widely known and used species in the genus Citrus is the lemon-Citrus limon (L.) Burm. f. (Latin synonyms: C.x limonia, C. limonum). Citrus fruits have been used by people for centuries for agricultural, medical and herbal purposes (25). Several pharmacological properties have been ascribed to different members of Citrus species. These properties are anticancer $(26,27,28,29,30)$, antifungal (31), antityphoid (29), anti-oxidant (32), antiulcer (33), hypolipidemic (34). Carvone and limonene have a broad range of anti-fungal and anti-microbial activities $(35,36)$. No studies with Citrus lemon flowers were found in the literature. As part of this study, various Citrus flower extracts were studied for antimicrobial, antioxidant and antibiofilms activities. This research aims to contribute to the lack of knowledge about the antimicrobial, antioxidant and antibiofilm activities of Citrus limon flowers.

\section{Material and Methods \\ Microorganisms and Cultivation}

In this work, Citrus limon flowers were singly tested against food pathogens such as Bacillus subtilis RSKK245, Staphylococcus aureus RSKK2392, Salmonella typhimurium RSKK19, Enterococcus faecalis ATCC8093, Escherichia coli ATCC11229, Listeria monocytogenes ATCC7644, Yersinia enterocolitica NCTC11174, and Candida albicans RSKK02029. The bacteria were grown for 24 hours, at $37^{\circ} \mathrm{C}$ in Mueller Hinton Broth (Merck). C. albicans was grown for $24-48$ hours, at $30^{\circ} \mathrm{C}$ in Sabouraud Dextrose Broth (Merck). These pathogens were provided from different culture collections. These strains of bacteria and C. albicans were obtained from ATCC (American Type Culture Collection, USA), RSKK (Refik Saydam National Type Culture Collection, Turkey), or NCTC (National Collection of Type Cultures).

\section{Plant material}

Citrus limon L. flowers were obtained from different local herbalists in the Mugla region, Turkey in 2019. The taxonomic identification of the plant was performed by Dr. Olcay CEYLAN (voucher number: 1300) from Mugla Sitki Kocman University, Turkey and a specimen was stored in the herbarium. The identity of this specimen was applied by the Flora of Turkey (37).

The flowers were cleaned thoroughly two to three times with flowing and sterile distilled water. These materials were dried by air. All of the samples were stocked at room temperature. Then, the plant parts pulverized in a disruptive mill. Then the plant parts were stocked at $4^{\circ} \mathrm{C}$ until needed for assay.

\section{Plant Extraction}

The dried matter ( $50 \mathrm{~g}$ of flower) was extracted with organic solvent $(250 \mathrm{ml}$ of ethanol, methanol, and water) using the Soxhlet device ( 8 hours). The materials have evaporated. Subsequently, the materials were stored in matte cylinders. These vials were stored and refrigerated for use $(300 \mathrm{mg} / \mathrm{ml})$.

\section{Antimicrobial Activity Assay}

In this study, the determination of Kirby-Bauer was applied for antibacterial activities (38). Bacteria were stored in plates of MHA at $37^{\circ} \mathrm{C}$. Microbiological cultures adjusted to $0.5 \mathrm{McFarland}$. Incubation of the bacteria took place at $37^{\circ} \mathrm{C}$ over a 24 -hour period. The yeast incubation was at $30^{\circ} \mathrm{C}$ during 24 hours. The assessment of antibacterial activity was based on measuring the diameter of the inhibition zones around the disks after 24 hours. Ethanol, methanol, water, chloramphenicol $(30 \mu \mathrm{g})$ and nystatine $(100 \mu \mathrm{g})$ were used as controls in this study. As well, the extract concentration was used at $300 \mathrm{mg} / \mathrm{ml}$.

\section{Minimum Inhibitory Concentration Assay (MIC)}

The MIC for plant extracts was measured using the broth dilution assay. The MIC values were reported as the lowest concentration of herbal extracts. The broth dilution test was performed according to the literature $(39,40,41)$. We have used final concentrations of the extract in our work. These concentrations were in the range of $13000 \mu \mathrm{g} / \mathrm{ml}$ to $1625 \mu \mathrm{g} / \mathrm{ml}(13000 ; 6500$; 3250; and $1625 \mu \mathrm{g} / \mathrm{ml}$ ).

\section{Determination of Non-Enzymatic Antioxidant Activity}

Two methods have been used for nonenzymatic antioxidant activity experiments. The nonenzymatic antioxidant activity was investigated with the free radical 1,1-diphenyl-2-picrylhydrazyl (DPPH). Stable DPPH was used to determine free radical sweep activities for the extracts. The extract $(0.1 \mathrm{ml})$ was added to the methanol DPPH mixture $(0.1 \mathrm{mM})$. This solution was incubated for 30 minutes, then the absorption of the solution was measured by spectrophotometry. Methanol was blank. Methanol with DPPH solution was utilized as a control variable (42). The free radical recovery capability expressed as a percentage (\%) was calculated from the formula.

The antioxidant activity of the flower extract was determined using ABTS [2,2'-azino-bis (3-ethyl benzothiazoline-6-sulfonic acid)], as described in (43). The radical sweep activity was determined within 15 minutes of incubation with extract. As documented, a 7 $\mathrm{mM}$ ABTS solution was mixed with a $2.4 \mathrm{mM}$ potassium persulphate solution. In order to maintain the stability of the ABTS radical, the mixture was left in darkness for 12 to 16 hours. Subsequently, $10 \mu \mathrm{l}$ of extract solution was added in $1 \mathrm{ml}$ of stable ABTS radical. The absorbence of this mixture (extract solution + stable ABTS radical) incubated over 15 minutes was measured at a wavelength of $734 \mathrm{~nm}$. The percentage ABTS ratios were determined by the absorbence values according to the formula given. 
In studies of antioxidant activity, trolox has been used as a positive control of radical sweeping activities. Results were reported as $\mathrm{mM}$ Trolox equivalent (TE)/g dry weight. To obtain the standard Trolox curve $(\mathrm{pH}$ 7.4), different concentrations of solvents were prepared $(0.25,0.5,1,1.5,2,2.5 \mathrm{mM})$ in $5 \mathrm{mM}$ saline phosphate buffer (PBS) and the absorbence of these samples was measured as described in (44).

\section{Antibiofilm activity assay}

Sterile 96-well polystyrene tissue culture plates were used as part of this study. Brain Heart Infusion Broth $(100 \mu \mathrm{l})$, culture $(50 \mu \mathrm{l})$ and plant extracts were placed in each well. Concentrations of plant extracts included $13000,6500,3250 \mu \mathrm{g} / \mathrm{ml}$. All plaques were incubated at $37^{\circ} \mathrm{C}$ for 24 hours. At the end of incubation, the plates were cleaned with phosphate buffered saline (PBS) three times. Once the nonadherent cells were removed, the plates were dried in the air. The purple crystal solution $(\% 0.4 \mathrm{w} / \mathrm{v})$ was added to the adhesive biofilm. Plates were incubated for about ten minutes. The absorbence measured at $570 \mathrm{~nm}$. The activities of antibiofilm were calculated using the literature formula (45).

\section{Thin Layer Chromatography}

Thin-layer chromatography was performed on the three extracts of Citrus limon (L) using a plate of alumina TLC whose surface was covered with silica gel. Thin-layer chromatography was carried out on slabs of silica gel 60F254 TLC (Merck, Germany, $1.05554 .0001)$. The TLC plate was $10 \mathrm{~cm} \times 10 \mathrm{~cm}$, with a pencil mark approximately $2 \mathrm{~cm}$ from the bottom edge of the original plate end. Prior to use, the plates used in
TLC were activated at $120^{\circ} \mathrm{C}$ during $10 \mathrm{~min}$. The extraction samples $(4 \mu \mathrm{L})$ were located on the chromatographic plates. The mixture of ethanol: hexane $(90: 10, \mathrm{v} / \mathrm{v})$ was used as the moving phase $(50 \mathrm{ml})$. The plates were developed vertically at room temperature $\left(20^{\circ} \mathrm{C}\right)$ to a distance of $7.5 \mathrm{~cm}$ in a mobile phase glass cabinet and dried for 24 hours at room temperature $\left(20^{\circ} \mathrm{C}\right)$ hood.

Stains of separate compounds were detected with a vanillin ethanol solution (1g vanillin, $100 \mathrm{ml}$ $95 \%$ ethanol and $10 \mathrm{ml} \mathrm{95 \%} \mathrm{sulphuric} \mathrm{acid} \mathrm{(VI)).} \mathrm{The}$ plate was heated to $100^{\circ} \mathrm{C}$ until the coloured stains were visible. Stains were detected through a UV transilluminator (CAMAG; Swiss; $\lambda=295 \mathrm{~nm}$ ).

The area of a point in the chromatogram matching the band was noted. The Rf value was calculated according to the formula.

\section{Statistical analysis}

In this study, the means of the activities were calculated with excel 2016.

\section{Results}

Antimicrobial activity studies were performed using a disc diffusion method. In this study, the highest inhibitory area was determined from the ethanol extract of the flower against Escherichia coli. This area is $12 \mathrm{~mm}$. Staphylococcus aureus was not affected by the flower extracts. The flower extracts were highly efficient against Candida. Ethanol extract produced a high inhibition area for Candida albicans (11 mm). However, the inhibitory zone of the nystatin antibiotic was $7 \mathrm{~mm}$ (Table 1).

Table 1. Antimicrobial activities of Citrus limon flower extracts $(300 \mathrm{mg} / \mathrm{ml})$

\section{Inhibition zone diameters Antibiotics \\ Solvents}

Microorganisms

\begin{tabular}{|c|c|c|c|}
\hline $\mathbf{E E}$ & $\mathbf{M E}$ & $\mathbf{A E}$ & $\mathbf{C}$ \\
\hline- & - & 8 & 12 \\
\hline- & - & - & 15 \\
\hline 8 & 7 & 7 & 22 \\
\hline 8 & - & 8 & 22 \\
\hline 12 & 11 & 9 & 22 \\
\hline- & - & 7 & 22 \\
\hline 8 & 7 & 9 & 20 \\
\hline 11 & 10 & 9 & nt \\
\hline
\end{tabular}

\begin{tabular}{|c|c|c|c|}
\hline N & E & M & A \\
\hline nt & - & - & - \\
\hline nt & - & - & - \\
\hline nt & - & - & - \\
\hline nt & - & - & - \\
\hline nt & - & - & - \\
\hline nt & - & - & - \\
\hline nt & - & - & - \\
\hline 7 & - & - & - \\
\hline
\end{tabular}

Bacillus subtilis RSKK245

Staphylococcus aureus RSKK2392

Salmonella typhimurium RSKK19

Enterococcus faecalis ATCC8093

Escherichia coli ATCC11229

Listeria monocytogenes ATCC7644

Yersinia enterocolitica NCTC11174

Candida albicans RSKK02029

EE: Ethanol extract; ME: Methanol extract; AE: Aqueous extract; C: Chloramphenicol; N: Nystatin; nt: not tested; (-): no inhibition

The other antibacterial activity test was MIC. The lowest MIC value is $3250 \mu \mathrm{g} / \mathrm{ml}$. This value was determined for Salmonella typhimurium, Enterococcus faecalis and Escherichia coli. The lowest MIC value was obtained using the aqueous extract of Citrus limon flowers (Table 2).

Table 2. Minimum inhibitory concentrations of Citrus limon extracts $(\mu \mathrm{g} / \mathrm{ml})$

\begin{tabular}{|c|c|c|c|}
\hline Microorganisms & EE & ME & $\mathbf{A E}$ \\
\hline Bacillus subtilis RSKK245 & $\mathrm{nt}$ & nt & 6500 \\
\hline Staphylococcus aureus RSKK2392 & $\mathrm{nt}$ & nt & nt \\
\hline Salmonella typhimurium RSKK19 & 13000 & 6500 & 3250 \\
\hline Enterococcus faecalis ATCC8093 & 6500 & $\mathrm{nt}$ & 3250 \\
\hline Escherichia coli ATCC11229 & 6500 & 6500 & 3250 \\
\hline Listeria monocytogenes ATCC7644 & nt & $\mathrm{nt}$ & 6500 \\
\hline Yersinia enterocolitica NCTC11174 & 13000 & 13000 & 13000 \\
\hline Candida albicans RSKK02029 & 6500 & 13000 & $>13000$ \\
\hline
\end{tabular}


The nonenzymatic antioxidant activity studies were performed by ABTS and DPPH radical scavenging. In the ABTS method, the strongest activity was determined using flower ethanol extract (53\%). In addition, DPPH scavenging activity was 95.4 percent (Table 3 ).

Table 3. Antioxidant activities of Citrus limon extracts $(300 \mathrm{mg} / \mathrm{ml})$

\begin{tabular}{|c|c|c|c|c|}
\hline \multicolumn{2}{|c|}{ Activity } & \multicolumn{3}{c|}{ DPPH } \\
\cline { 1 - 5 } Extracts & Scavenging activity (\%) & TE & Scavenging activity (\%) & TE \\
\hline EE & 58.3 & 1.95 & 75.2 & 2.31 \\
\hline ME & 52.15 & 1.85 & 95.4 & 2.57 \\
\hline AE & 52.34 & 1.85 & 87.4 & 2.46 \\
\hline
\end{tabular}

TE: mM Trolox equivalent/ g DW; EE: Ethanol extract; ME: Methanol extract; AE: Aqueous extract; DW: Dry weight

Citrus limon extracts showed an effective antibiofilm action against the strains tested. However, none of the extracts could completely inhibit the formation of bio-film. At the MIC value in this study, Citrus limon flower methanol extract had the highest inhibition rate (20.4\%) against Escherichia coli biofilm formation. Extracts of Citrus limon have been found to inhibit the formation of biofilm of Enterococcus faecalis, Escherichia coli, Salmonella typhimurium, Candida albicans and Bacillus subtilis. The best reduction in biofilm is observed at higher concentrations of extracts (Citrus limon AE 56.9\%). The aqueous extract of Citrus limon at a concentration of $13000 \mu \mathrm{g} / \mathrm{ml}$ showed the highest antibiofilm activity (56.9\%) against the formation of Bacillus subtilis biofilm. The ethanolic extract of Citrus limon flowers at a concentration of $13000 \mu \mathrm{g} / \mathrm{ml}$ showed the highest inhibition rate $(32.9 \%)$ against the formation of Listeria monocytogenes biofilms while the methanolic extract of Citrus limon exhibited a $52.7 \%$ inhibition of the formation of Salmonella typhimurium biofilms at a concentration of $13000 \mu \mathrm{g} / \mathrm{ml}$ (Table 4).

The presence of various phytoconstituents was confirmed by thin-layer chromatography. The number of points observed and their corresponding $\mathrm{Rf}$ values are given in Figures 1 and 2. Three spots with $R f$ values of $0.53,0.60$ and 0.64 were observed for ethanol extract from Citrus limon, whereas three spots with $\mathrm{Rf}$ values of $0.52,0.69$ and 0.77 were observed for methanol extract, respectively. However, two spots were identified from the aqueous extraction (Figure 1 and 2).

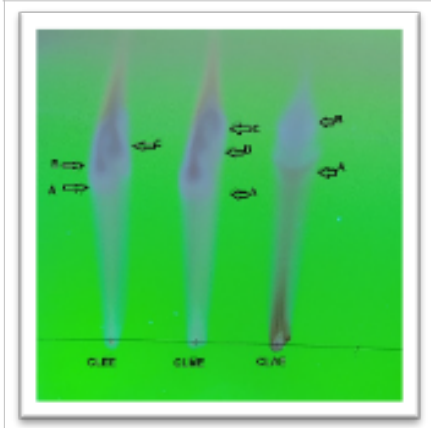

Figure 1: a) The chromatogram of compounds in UV of Citrus limon flower extracts

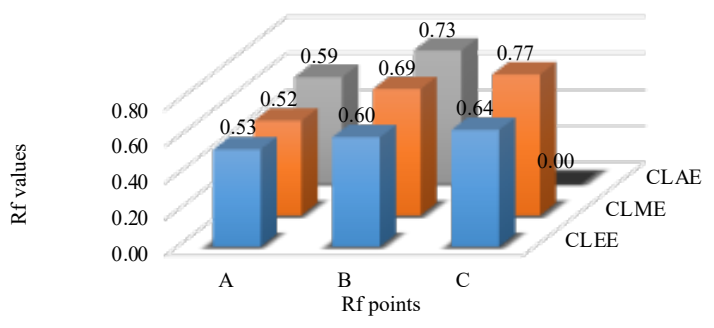

CLEE $\square$ CLME $\backsim$ CLAE

Figure 2: The Rf values of Citrus limon extracts CLEE: Citrus limon ethanol extract; CLME: Citrus limon methanol extract; CLAE: Citrus limon aqueous extract

Table 4. Antibiofilm activities of Citrus limon extracts

\begin{tabular}{|c|c|c|c|c|c|c|c|c|c|}
\hline \multirow{5}{*}{ Organisms } & \multicolumn{9}{|c|}{ Extracts } \\
\hline & \multicolumn{3}{|c|}{ EE } & \multicolumn{3}{|c|}{ ME } & \multicolumn{3}{|c|}{$\mathbf{A E}$} \\
\hline & \multicolumn{9}{|c|}{ Concentrations of extracts $(\mu \mathrm{g} / \mathrm{ml})$} \\
\hline & 13000 & 6500 & 3250 & 13000 & $\mathbf{6 5 0 0}$ & 3250 & 13000 & 6500 & 3250 \\
\hline & \multicolumn{9}{|c|}{ Inhibition rates (\%) } \\
\hline B. subtilis RSKK245 & 27.7 & 7.8 & 3.0 & 46.4 & 35.5 & 8.7 & 56.9 & 27.3 & 8.9 \\
\hline S. aureus RSKK2392 & 17.1 & 3.4 & 1.9 & 39.0 & 24.2 & 19.3 & 36.5 & 18.3 & 5.0 \\
\hline S. typhimurium RSKK19 & 11.7 & 3.6 & 1.4 & 52.7 & 22.6 & 13.3 & 28.9 & 18.2 & 10.8 \\
\hline E. faecalis ATCC 8093 & 13.9 & 9.6 & 1.9 & 31.1 & 25.1 & 9.5 & 46.2 & 26.9 & 13.8 \\
\hline E. coli ATCC11229 & 16.6 & 11.7 & 10.3 & 46.0 & 33.4 & 20.4 & 36.8 & 25.7 & 9.3 \\
\hline L. monocytogenes ATCC7644 & 32.9 & 10.1 & 5.3 & 25.1 & 17.9 & 13.7 & 21.1 & 7.0 & 3.6 \\
\hline Y. enterocolitica NCTC11174 & 18.6 & 16.7 & 11.9 & 35.4 & 17.1 & 0.7 & 37.9 & 22.9 & 6.2 \\
\hline C. albicans RSKK02029 & 32.0 & 19.9 & 5.4 & 21.0 & 11.7 & 3.7 & 44.3 & 29.5 & 10.0 \\
\hline
\end{tabular}

EE: Ethanol extract; ME: Methanol extract; AE: Aqueous extract

In this study, three metabolites were found in ethanol and methanol extracts, while two metabolites were found in the aqueous extract (Figure 2). 


\section{Discussion}

Medicinal plants play a major role in the prevention of various diseases and have attracted the attention of numerous researchers in recent years. Herbs and essential oils have served as preservatives and sweetening agents in foods for years. The use of synthetic additives and antimicrobials, which have increased with developing technology, has identified problems such as many side effects on the health and resistance of microorganisms to synthetic antimicrobials, and there is a need to look at additional resources.

In this study, the highest anti-bacterial activity was determined against $E$. coli and this area was 12 $\mathrm{mm}$. However, $8 \mathrm{~mm}$ inhibition zones were found for $S$. typhimurium, E. faecalis and Yersinia enterocolitica, 11 $\mathrm{mm}$ for Candida albicans (Table 1). Okmen et al. (46) reported that cyclamen ethanolic extract was inhibited by $10 \mathrm{~mm}$ against $E$. coli. During the study, Otang and Afolayan (47) detected a $20 \mathrm{~mm}$ inhibition zone for $S$. typhimurium and a $15 \mathrm{~mm}$ inhibition zone for E. coli. Hindi and Chabuck (48) studied the peel, juice and dried form of Citrus limon in their study and received different results. Although the peeled parts are effective for $S$. aureus $(30 \mathrm{~mm})$ and $E$. faecalis $(30 \mathrm{~mm})$, their juice is effective for $S$. aureus (26 mm), E. faecalis (28 $\mathrm{mm})$, Candida albicans $(30 \mathrm{~mm})$, E. coli $(10 \mathrm{~mm})$ and Salmonella Typhi $(30 \mathrm{~mm})$. While the literature results are consistent with our studies, there are also differences. This may be because of different phytochemical composition in different parts of the plant, different extraction processes, and environmental factors, as well as differences in the genotypes of the plant used. Tajkarimi et al. (49) reported that plantbased substances can have antimicrobial effects through a variety of mechanisms, including by attacking the phospholipid bilayer in the cell membrane of the bacterium, by interfering with enzymatic systems or by altering genetic material.

In the current study, the MIC for Salmonella typhimurium, E. faecalis and E. coli was $3250 \mu \mathrm{g} / \mathrm{ml}$ (Table 2). Rahman et al. (50) reported that Citrus limon's MIC value for Salmonella Typhi was $3125 \mathrm{ppm}$. Ewansiha et al. (51) found the MIC for C. limon peel essential oils for $S$. Typhi to be $50 \mathrm{mg} / \mathrm{ml}$. These literatures-based results are parallel to our studies, but there are a few differences. These differences may be due to differences in sample cultures, substance levels and extraction methods for essential oils (52). The mechanism of the antimicrobial activity of essential oils is associated with the attack of phospholipids present in the cell membrane, thereby increasing the permeability and leaching of the cytoplasm or their interaction with enzymes located in the cell wall. This means that phenolic compounds in essential oils inhibit the growth of microorganisms by sensitizing the cell membrane phospholipid bilayer, thus increasing its permeability and leading to leakage of vital intracellular components or disruption of bacterial enzyme systems $(53,54,55$, 56, 57). Danila et al. (58) reported that C. limon contains numerous monoterpenes, oxygenated monoterpenes and sesquiterpenes.

Recently, interest in natural antioxidants has grown steadily because synthetic antioxidants have side effects such as carcinogenesis. In the current study, the highest antioxidant activity of Citrus limon was determined from the ethanol extract by ABTS method, with a scavenging rate $58.3 \%$. However, the highest antioxidant potency of methanol extract was found to be $95.4 \%$ in the DPPH method (Table 3 and 4 ).

$\mathrm{Xi}$ et al. (59) reported that the greatest DPPH recovery activity from the peel was $7.45 \mu \mathrm{M} \mathrm{TE} / \mathrm{g} \mathrm{DW}$, while the greatest ABTS recovery activity was $8.65 \mu \mathrm{M}$ TE/g DW from the peel of the plant. Yang et al. (60) found that lemon has greater scavenging activity than mint in their study. Oekeh et al. (61) examined the antioxidant activity of various fruit juices and reported DPPH scavenging activity in lemon juice to be $5 \%$. Makni et al. (62) indicated that the antioxidant activity $(70 \%)$ of tasty lemon at $1000 \mu \mathrm{g} / \mathrm{ml}$ was higher than that of succulent lemon (20\%). Rowshan and Najafian (63) reported that the scavenging activity for DPPH from Citrus limetta skin was $87.7 \%$. Differences in radical scavenging activities may depend on geographical origins, weather and seasonal conditions, collection time, stage of development, extraction method and the presence of new chemotypes (64). It can be linked to changes in the chemical content of plants, soil composition, daily or seasonal changes in plant material during collection, physiological development of plants, with the type of bacteria $(65,66$, $67,68)$.

Thin-layer chromatography is usually carried out to better identify bioactive compounds. This study demonstrated that TLC profiling of all plant extracts had diverse metabolites such as alkaloids, flavonoids, phenols and tannins. Among the three solvents (ethanol, methanol and water), ethanol and methanol were observed to be efficient at extracting the maximum number of secondary metabolites (Figure 1 and 2). Kumar et al. (69) have also reported various phytochemical compounds in lemon peel ethanolic extract. Various $\mathrm{Rf}$ values of the compounds give an idea of their polarity which can also help to choose a particular solvent system for the additional isolation of any compound of plant extracts using chromatographic and spectroscopic techniques (70). The sites from which plant samples were collected are of varying altitudes, soil $\mathrm{pH}$, and soil types, which likely contributed to differences in the phytochemical composition of plant samples. This is consistent with earlier findings that plants growing in areas of different altitudes and soil types have different phytochemical compositions (71, 72).

\section{Conclusion}

In this study, different extracts of Citrus limon have different effects against microorganisms. One of the most important outcomes of this study is radical scavenging activities. The presence of strong antioxidants in all extracts has been observed by DPPH 
research. Citrus limon extracts can be beneficial as a good anti-oxidant protective system for the human body against oxidative damage. Based on the current findings, it can be suggested that herbal extracts can be used as a source of a natural antibacterial compound with strong antioxidant potential. The study reveals that C. limon flowers are a rich source of active compounds with diverse medicinal and pharmacological properties that make it an attractive product, alternative, and cheap source of functional ingredients for functional food and nutraceutical formulation. However, further studies are required to focus on in vivo studies using biologically active compounds. As well, further studies are required for fractions, characterization, and study of active ingredients.

\section{Conflict of interest}

The authors state that there is no conflict of interest concerning the publication of this document.

\section{Acknowledgments}

The authors thank Dr. Olcay Ceylan (Mugla Sitki Kocman University, Turkey) for identification of plants.

This study was presented as an oral presentation at the 5th International Engineering and Natural Sciences Conference (IENSC 2020) hold from November 5 to 6,2020 , in Diyarbakir, Turkey. It was published as an abstract paper in the proceeding book of the IENSC-2020.

\section{References}

1. WHO (World Health Organisation). The Burden of Foodborne Diseases in the Who European Region, Foodborne Disease Burden Epidemiology Reference Group; 2007- 2015; 2017.

2. Sofos JN, Beuchat LR, Davidson PM, Johnson EA, Naturally occurring antimicrobials in food. Regul. Toxicol. Pharmacology 1998; 28; 71-72.

3. Gyawali R, Ibrahim SA, Natural products as antimicrobial agents. Food Control 2014; 46; 412429.

4. Calo JR, Crandall PG, O'Bryan CA, Ricke SC, Essential oils as antimicrobials in food systems - a review. Food Control 2015; 54; 111-119.

5. Shivendu R, Nandita D, Proud S, Madhumita R, Ramalingam C, Advances in Applied Science Research 2012; 3 (1); 495-501.

6. Neenu AS, Anto PV, Neethu BN, Evaluation on Antimicrobial Activity of Fruit Peels of Selected Citrus Species against Human Pathogenic Microorganism. Journal of Pharmacognosy and Phytochemistry 2015; 4(3); 278-81.

7. Bansode DS, Chavan MD, Studies on Antimicrobial Activity and Phytochemical Analysis of Citrus Fruit Juices Against Selected Enteric Pathogens. International Research Journal of Pharmacy 2012; 3(11); 122-6.

8. Karteek P, Jahnavi V, Keerthi DV, Sravanthi KC, Evaluation of Antibacterial Activity of Herbs. International Research Journal of Pharmacy 2012; $3(8) ; 230-2$.
9. Parekh J, Jadeja D, Chanda S, Efficacy of aqueous and methanol extracts of some medicinal plants for potential antibacterial activity. Turk. J. Biology 2005; 29;203-210.

10. Gomes F, Leite B, Teixeira P, Oliveira R. In: Méndez-Vilas, A. (Ed.) Strategies to Control Staphylococcus epidermidis Biofilms, Science Against Microbial Pathogens: Communicating Current Research and Technological Advances; 2011; 843-852.

11. Alabdullatif M, Boujezza I, Mekni M, Taha M, Kumaran D, Yi QL, Landoulsi A, Ramirez-Arcos S, Enhancing blood donor skin disinfection using natural oils. Transfusion 2017; 57; 2920-2927.

12. Gavahian M, Farahnaky A, Javidnia K, Majzoobi M, Comparison of ohmicassisted hydrodistillation with traditional hydrodistillation for the extraction of essential oils from Thymus vulgaris L. Innov. Food Sci. Emerg. Technology 2012; 14; 85-91.

13. Moradalizadeh M, Samadi N, Rajaei P, Comparison of hydrodistillation, microwave hydrodistillation and solvent free microwave methods in analysis of the essential oils from aerial parts of Haplophyllum robustum Bge by GC/MS method. IJABBR 2013; 1; 1058-1067.

14. Olson ME, Ceri H, Morck DW, Buret AG, Read RR, Biofilm bacteria: formation and comparative susceptibility to antibiotics. Can. J. Vet. Research 2002; 66; 86-92.

15. Sadaka F, Nguimjeu C, Brachais CH, Vroman I, Tighzert L, Couvercelle JP, Review on antimicrobial packaging containing essential oils and their active biomolecules. Innovative Food Science and Emerging Technologies 2013; 20; 350-355.

16. Fisher K, Phillips C, The mechanism of action of a citrus oil blend against Enterococcus faecium and Enterococcus faecalis. Journal of Applied Microbiology 2009; 106; 1343-1349.

17. Agyare C, Asase A, Lechtenberg M, Niehues M, Deters A, Hensel A, An ethnopharmacological survey and in vitro confirmation of ethnopharmacological use of medicinal plants used for wound healing in Bosomtwi-AtwimaKwanwoma area, Ghana. Journal of Ethnopharmacology 2009; 1253; 393-403.

18. Jonas W, Kaptehuk T, Linde K, A critical overview of homeopathy. Annals of Internal Medicine 2003; 138; 393-39.

19. Brul S, Coote P, Preservative agents in foods: Mode of action and microbial resistance mechanisms. Int. J. Food Microbiology 1999; 50(1-2); 1-17.

20. Dupont S, Caffin N, Bhandari B, Dykes GA, In vitro antibacterial activity of Australian native herb extracts against food-related bacteria. Food Control 2006; 17(11); 929-932.

21. Nascimento GG, Locatelli J, Freitas PC, Silva GL, Antibacterial activity of plant extracts and phytochemicals on antibiotic resistant bacteria. Braz. J. Microbiology 2000; 31; 247-256.

22. Kamal GM, Anwar F, Hussain AI, Sarri N, Ashraf MY, Yield and chemical composition of Citrus 
essential oils as affected by drying pretreatment of peels. Inter. Food Res. Journal 2011; 18;1275-82.

23. Ahmed W, Pervez MA, Amjad M, Khalid M, Ayyub CM, Nawaz MA, Effect of stionic combination on the growth and yield of Kinnow mandarin (Citrus reticulata Blanco). Pak. J. Botany 2006; 38(3); 603-612.

24. Mabberley DJ, Citrus (Rutaceae): A review of recent advances in etymology, systematics and medical applications. Blumea J. Plant Taxon. Plant Geography 2004; 49; 481-498.

25. Tomar A, Mall M, Rai P, Pharmacological importance of Citrus fruits. International Journal of Pharmaceutical Science and Research. 2013; 4(1); 156-160.

26. Jacob R, Hasegawa S, Manners G, The potential of citrus limonoids as anticancer agents. Perishables Handling Quarterly 2000; 102; 6-8.

27. Silalahi J, Anticancer and health protective properties of citrus fruit components. Asia Pac. J. Clin. Nutr. 2002; 11(1); 79-84.

28. Enterazi M, Majid A, Falahian F, et al., Antimutagenic and anti-cancer effects of Citrus medica fruit juice. Acta Med. Iron. 2009; 47(5); 373-377.

29. Kumar KA, Narayani M, Subanthini A, et al., Antimicrobial activity and phytochemical analysis of citrus fruit peels-utilization of fruit waste. International Journal of Engineering Science and Technology 2011; 3(6); 5414-5421.

30. Lawal HO, Adewuyi GO, Fawehinmi AB, et al., Bioassay of herbal mosquito repellant formulated from the essential oils of plants. Journal of Natural Products 2012; 5;109-115.

31. Valezquez-Nunez MJ, Avila-Sosa R, Palou E, et al., Antifungal activity of orange peel essential oil applied directly or vapour contact. Food Control 2013; 3(1); 1-4.

32. Duda-Chodak A, Tarko T, Antioxidant properties of different fruits seeds and peels. Acta Sci. Pol. Technol. 2007; 6(3); 29-36.

33. Nagaraju B, Anand SC, Ahmed N, et al., Antiulcer activity of extracts of Citrus medica Linn. fruit against ethanol-induced ulcer in rats. Advances in Biological Research 2012; 6(1); 24-29.

34. Khan Y, Khan RA, Syeda, et al., Evaluation of hypolipidemic effect of Citrus lemon. Journal of Basic and Applied Sciences 2010; 6(1); 39-43.

35. Berk Z, "Morphology and Chemical Composition" in Citrus Fruit Processing, New York: Elsevier 2016; 13-29.

36. Vimal M, Vijaya PP, Mumtaj P, Farhath MSS, Antibacterial Activity of Selected Compounds of Essential Oils from Indigenous Platnts. Journal of Chemical and Pharmaceutical Research 2013; 5(1); 248-53.

37. Davis PH, Flora of Turkey and the East Aegean Islands. I-X. Edinburg Unv. Press, Edinburg. 1965-1988.

38. Bauer AW, Kirby WMM, Sherris JC, Turck M, Antibiotic susceptibility testing by a standardized single disk method. Am. J. Clin. Pathology 1966; 45(4); 493-496.

39. Mazzanti G, Mascellino MT, Battinelli L, Coluccia D, Manganaro M. Saso L, Antimicrobial investigation of semipurified fractions of Ginkgo biloba leaves. J. Ethnopharmacology 2000; 71; 83-88.

40. Devienne KF, Raddi MSG, Screening for antimicrobial activity of natural products using a microplate photometer. Braz. J. Microbiology 2002; 33; 166-168.

41. EUCAST, European committee on antimicrobial susceptibility testing, European Society of Clinical Microbiology and Infectious Diseases. 2014; http:// www.eucast.org/.

42. Brand-Williams W, Cuvelier ME, Berset C, Use of a free radical method to evaluate antioxidant activity. Food Sci. Technology 1995; 28; 25-30.

43. Re R, Pellegrini N, Proteggente A, Pannala A, Yang M, Rice-Evans C, Antioxidant activity applying an improved ABTS radical cation decolorization assay. Free Radic. Biol. Medical 1999; 26; 1231-1237.

44. Miller NJ, Rice-Evans C, Davies MJ, Gopinathan V, Milner A, A novel method for measuring antioxidant capacity and its application to monitoring the antioxidant status in premature neonates. Clin. Science 1993; 84; 407-412.

45. Saad MA, Rahmad O, Salman I, et al., Antibiofilm activity, compound characterization, and acute toxicity of extract from a novel bacterial species of Paenibacillus. Int. J. Microbiol. 2014; Volume 2014; 11 pages.

46. Okmen G, Ceylan O, Erdal P, Işık D, Bayrak D, Kardaş Ş, Görk G, Arslan A, Gida Patojenlerine Karşı Cyclamen mirabile Hildebr. Kök Özütlerinin Antimikrobiyal Aktivitesi Üzerine Bir Çalışma. Anadolu Doğa Bilimleri Dergisi 2014; 5(2); 1-7. (in Turkish).

47. Otang WM, Afolayan AJ, Antimicrobial and antioxidant efficacy of Citrus limon L. peel extracts used for skin diseases by Xhosa tribe of Amathole District, Eastern Cape, South Africa. South African Journal of Botany 2016; 102; 46-49.

48. Hindi NKK, Chabuck ZAG, Antimicrobial activity of different aqueous lemon extracts. Journal of Applied Pharmaceutical Science 2013; 3(06); 74-78.

49. Tajkarimi MM, Ibrahima SA, Cliver DO, Antimicrobial herb and spice compounds in food. Food Control 2010; 21; 1199-1218.

50. Rahman FHF, Alimsardjono L, Zakaria S, In vitro antimicrobial potency of lemon fruit (Citrus limon) extract on Salmonella Typhi. JUXTA: Jurnal Ilmiah Mahasiswa Kedokteran Universitas Airlangga 2020; XI (02); 69-73.

51. Ewansiha JU, Garba SA, Galadima M, Daniyan SY, Busari MB, Therapeutic potency of Citrus limon (L) Burm. F. (Lemon) peel extract against some disease causing microorganisms. International Journal of Research Studies in Biosciences (IJRSB) 2016; 4(11); 30-39. 
52. Oukerrou MA, Tilaoui M, Mouse HA, Leouifoudi I, Jaafari A, Zyad A, Chemical composition and cytotoxic and antibacterial activities of the essential oil of Aloysia citriodora Palau grown in Morocco. Advances in Pharmacological and Pharmaceutical Sciences 2017; Volume 2017; 10 pages.

53. Sokovic M, Glamočlija J, Marin PD, Brkić D, van Griensven LJLD, Antibacterial effects of the essential oils of commonly consumed medicinal herbs using an in vitro model. Molecules 2010; 15; 7532-7546.

54. Muppalla SR, Kanatt SR, Chawla S, Sharma A, Carboxymethyl cellulose-polyvinyl alcohol films with clove oil for active packaging of ground chicken meat. Food Packag Shelf Life 2014; 2(2); 51-58.

55. Shad AA, Ahmad S, Ullah R, et al., Phytochemical and Biological Activities of Four Wild Medicinal Plants. The Scientific World Journal 2014; 7.

56. Suerni E, Uji Daya Hambat Ekstrak Buah Nanas (Ananas comosus L. Merr.), Salak (Salacca edulis Reinw.) dan Mangga Kweni (Mangifera odorata Griff.) terhadap Daya Hambat Staphylococcus aureus. Biocelebes, 2015; 7(1); 35-47.

57. Dhifi W, Bellili S, Jazi S, Bahloul N, Mnif W, Essential oil's chemical characterization and investigation of some biological activities: a critical review. Medicines 2016; 3; 1-16.

58. Danila E, Moldovan Z, Popa M, Chifiriuc MC, Kaya AD, Kaya MA, Chemical composition, antimicrobial and antibiofilm efficacy of $C$. limon and L. angustifolia EOs and of their mixtures against Staphylococcus epidermidis clinical strains. Industrial Crops \& Products 2018; 122; 483-492.

59. Xi W, Lu J, Qun J, Jiao B, Characterization of phenolic profile and antioxidant capacity of different fruit part from lemon (Citrus limon Burm.) cultivars. J. Food Sci. Technology 2017; 54(5); 1108-1118.

60. Yang SA, Jeon SK, Lee EJ, Shim CH, Lee IS, Comparative study of the chemical composition and antioxidant activity of six essential oils and their components. National Product Research 2010; 24; $140-151$.

61. Oikeh EI, Omoregie ES, Oviasogie FE, Oriakhi K, Phytochemical, antimicrobial, and antioxidant activities of different citrus juice concentrates. Food Science \& Nutrition 2016; 4(1); 103-109.

62. Makni M, Jemai R, Kriaa W, Chtourou Y, and Fetoui H, Citrus limon from Tunisia: Phytochemical and physicochemical properties and biological activities. BioMed. Research International 2018; Volume2018; 10 pages.

63. Rowshan V, and Najafian S, Headspace analyses of leaf and flower of Citrus limetta (Lemon), Citrus maxima (Pomelo), Citrus sinensis (Orange), and Citrus medica (Cedrum) for volatile compounds by combi-PAL System Technique. Journal of Herbs, Spices \& Medicinal Plants 2013; 19(4); 418-425.

64. Saeed S, and Tariq $\mathrm{P}$, In vitro antibacterial activity of clove against Gram negative bacteria. Pakistan Journal of Botany 2008; 40(5); 2157-2160.

65. Keles OS, Bakirel AT, and Alpinar K, Screening of some Turkish plants for antibacterial activity. Turk. J. Vet. Anim. Sciences 2001; 25(4); 559-565.

66. Izzo AA, Di Carlo G, Bicardi D, De Fusco R, Mascolo N, Borrelli F, Capasso F, Biological screening of Italian medicinal plants for antibacterial activity. Phytotherapy Research 1995; 9(4); 281-286.

67. Martinez MJ, Betancourt J, Alonso-Gonzales $\mathrm{N}$, Jauregui A, Screening of some Cuban medicinal plants for antibacterial activity. J. Ethnopharmacol. 1996; 52(3); 171-174.

68. Tunon H, Olavsdotter C, Bohlin L, Evaluation of anti-inflammatory activity of some Sweedish medicinal plants. Inhibition of prostaglandin biosynthesis and PAF-induced exocytosis. J. Ethnopharmacol. 1995; 48(2); 61-76.

69. Kumar SP, Pushpak A, Shilpi M, Anup K, Shraddha $\mathrm{V}$, Phytochemical analysis of Citrus limonum and Citrus sinesis peels and identification of $\beta$ carotene pigment using ethanolic extract. International Research Journal of Pharmacy 2014; 5(10); 789-791.

70. Biradar RS, Rachetti DB, Extraction of some secondary metabolites \& thin layer chromatography from different parts of Centella asiatica L. American Journal of Life Sciences 2013; 1(6); 243-247.

71. Ubani CS, Oje OA, Ihekogwo FNP, Eze EA, Okofor CL, Effect of varying soil minerals and phytochemical parameters on antibacterial susceptibility of Mitracarpus villosus ethanol extracts; using samples from south east and southsouthern regions of Nigeria. Global Advanced Research Journal of Microbiology 2012; $1(7) ; 120-125$.

72. Rauf A, Rehma WU, Jan MR, Muhammad N, Phytochemical, phytotoxic and antioxidant profile of Caralluma tuberculata NE Brown. Wudpecker J. Pharm. and Pharmacol. 2013; 2; 021-025. 